Jurnal Emik, Volume 4 Nomor 2, Desember 2021

\title{
Pola Hidup Sehat Mahasiswa di Masa Pandemi Covid-19: Studi Kasus di Kelurahan Tombolo, Kabupaten Gowa
}

\author{
Muh. Akram Lawarani \\ Universitas Hasanuddin \\ lawaraniaan@gmail.com
}

\begin{abstract}
The Covid-19 pandemic, which has been endemic since the end of 2019 until the end of 2020, has claimed many victims. One way to prevent the spread is by implementing a healthy lifestyle that may increase immunity and endurance, and many of those infected are people aged 50 years and over who have a history of chronic diseases and congenital diseases. Therefore, many young people feel they don't need to be afraid of Covid-19 and don't pay too much attention to a healthy lifestyle. Students who are between late teens and early twenties are a busy age, both in terms of academic activities and non-academic activities, often making them neglect a healthy lifestyle. This article deals with healthy life pattern among college students.
\end{abstract}

This qualitative study was conducted in the village of Tombolo, Gowa Regency between October and December 2020. This location was chosen because based on data, those infected with Covid-19 in this location are relatively low. Data collection was carried out by in-depth interviews with 10 college student, consisting of five men and five women, aged between 19 and 23 years.

The study shows that in 2016 the government had launched the Healthy Living Community Movement (GERMAS). Although the government has recommended prevention of Covid19 with the $3 M$ movement (washing hands, wearing masks, maintaining distance), GERMAS is revealed in the form of activities that support more complex Covid-19 prevention which include: washing hands with soap, eating balanced nutritious food, exercise and adequate rest, maintain environmental hygiene, do not smoke, drink eight glasses of mineral water/day, eat perfectly cooked food and do not eat meat from animals that have the potential to transmit, if fever and shortness of breath go to a health facility immediately, wear a mask if cough or cover your mouth with the inside of your upper arm, and pray. Students' perceptions of a healthy lifestyle are related to how a person pays attention to eating/drinking, physical activities (exercise), and their resting time to avoid Covid-19. These perceptions are intertwined with the healthy lifestyle applied by students, in the form of personal hygiene patterns, eating patterns, exercise patterns, and resting patterns.

Keywords: Students, pandemic, Covid-19, healthy life pattern, and life style.

\section{Pendahuluan}

Kesehatan merupakan salah satu faktor terpenting dalam kehidupan untuk mendukung berjalannya aktivitas secara optimal. Kesehatan tidak saja berkaitan dengan kondisi fisik, tapi juga berassosiasi dengan kondisi mental dan sosial yang terbebas dari gangguan penyakit. Agar dapat mencapai standar kesehatan yang baik, maka diperlukan adanya proses pengelolaan lingkungan sekitar dan aktivitas harian yang terefleksi dalam gaya hidup sehat, yakni gaya hidup masyarakat yang menjunjung tinggi aspek- 
Pola Hidup Sehat Mahasiswa di Masa Pandemi Covid-19...

aspek kesehatan, seperti pengelolaan kebersihan dan kesehatan lingkungan, menjaga kebugaran fisik dan psikis dan pemberian asupan nutrisi yang cukup (Susanti dan Kholisoh 2018:1).

Pola hidup sehat, menurut Soenarjo (2002:17), adalah upaya untuk menerapkan kebiasaan yang baik dalam menciptakan hidup yang sehat dan menghindari kebiasaan buruk yang dapat mengganggu kesehatan. Oleh karenanya, pola hidup sehat merupakan sesuatu hal yang sangat penting serta sangat perlu untuk diperhatikan agar kualitas hidup menjadi jauh lebih baik lagi, serta dapat meningkatkan imunitas tubuh untuk meminimalisir akan terkenanya penyakit berbahaya ataupun virus yang dapat membahayakan tubuh.

Sejak akhir tahun 2019 hingga kini, dunia termasuk Indonesia dilanda wabah Covid-19 yang merupakan keluarga besar virus yang menjangkiti manusia dan hewan dan menyerang saluran pernapasan dengan gejala demam, batuk, dan sesak nafas. Corona virus merupakan virus jenis baru yang ditemukan pada manusia sejak kejadian luar biasa muncul di Wuhan, Cina pada Desember 2019, dan disebut Covid-19 dengan masa inkubasi rata-rata lima hingga 14 hari. Pada kasus Covid-19 yang berat dapat menyebabkan pneumonia, sindrom pernafasan akut, gagal ginjal dan bahkan kematian. Hingga 20 September 2020 terdapat total 244.676 orang yang dinyatakan terinfeksi Covid-19. ${ }^{1}$

Di Inggris dan China, disebutkan 41 kematian yang terjadi akibat virus ini, 39 diantaranya terjadi pada usia pasien di atas 50 tahun. ${ }^{2}$ Ada paling tidak dua alasan mengapa orang yang berusia lima puluhan ke atas lebih rentan terinfeksi Covid-19. Pertama, karena

\footnotetext{
${ }^{1}$ https://infeksiemerging.kemkes.go.id/, diakses tanggal 20 September 2020.

${ }^{2}$ https://www.kompas.com/tren/read/2020/02/01/1715 00165/orang-tua-atau-anak-anak-yang-lebih-rentanterhadap-virus-corona-?page $=$ all, diakses tanggal 15 Oktober 2020.
}

mereka potensil memiliki kondisi sakit yang lebih kronis, seperti diabetes atau penyakit paru. Ini membuat mereka kesulitan untuk menghadapi serangan pathogen virus baru. Kedua, sistem kekebalan tubuh menurun seiring bertambahnya usia dan ini berkelindan dengan melemahnya kemampuan untuk merespons virus, seperti Covid-19. ${ }^{3}$

Mahasiswa yang masih berusia relatif muda (between late teens and early twenties) seringkali kurang memperhatikan pola hidup sehat, baik sebelum maupun selama pandemi Covid-19 dikarena berbagai faktor mulai dari jadwal aktifitas kampus yang padat dan karena memang cenderung memiliki fisik yang masih relative bugar dibandingkan orang tua, sehingga jarang memerhatikan pola hidup sehat itu sendiri, hal itu juga cukup didukung dari data kasus positif dari kelurahan Tombolo di bulan januari hingga desember 2020 tercatat ada 11 kasus positif untuk usia 19 hingga 25 tahun dari total 101 kasus, hal ini menunjukkan cukup rendahnya kasus positif di kalangan anak muda kisaran umur tersebut.

Hasil studi pendahuluan yang dilakukan oleh Sani (2011) pada 30 mahasiswa (masingmasing 15 mahasiswa dan mahasiswi) Universitas Muhammadiyah Surakarta menunjukkan bahwa 13 mahasiswa laki-laki adalah perokok aktif dan pernah mengonsumsi minuman keras, sebagian mahasiswa perempuan jarang berolah raga, pola istirahat tidur yang tidak teratur dan kadang tidur larut malam bahkan sampi begadang, serta sering membuang sampah di sembarang tempat. Dengan mewabahnya Covid-19, maka seluruh lapisan masyarakat, termasuk mahasiswa

${ }^{3}$ https://www.kompas.com/tren/read/2020/02/01/1715 00165/orang-tua-atau-anak-anak-yang-lebih-rentanterhadap-virus-corona-?page=all, diakses tanggal 8 Desember 2020. 
dihimbau untuk waspada dan senantiasa menjaga imunitas, serta mengikuti protokol kesehatan demi memutus mata rantai penyebaran Covid-19.

Dalam studinya tentang gaya hidup masyarakat Nusa Tenggara Timur pada masa tanggap darurat Covid-19, Utama (2020) menunjukkan bahwa dari 191 responden yang terlibat dalam penelitian ini, $47,64 \%$ mengalami perubahan kebiasaan selama pandemi Covid-19. $39,27 \%$ responden mengonsumsi sayur dan buah, dan 30,89\% berjemur dan melakukan aktifitas fisik dengan frekuensi lebih dari tiga kali seminggu. Namun, perubahan yang paling signifikan terjadi pada penggunaan masker ketika keluar rumah $(98,43 \%)$, menggunakan sabun ketika mencuci tangan $(85,34 \%)$, dan mengonsumsi makanan segar $(77,49$. Ini mengindikasikan bahwa meskipun masyarakat belum sepenuhnya mematuhi anjuran pemerintah dalam pencegahan Covid-19, ada perubahan gaya hidup masyarakat yang terkait dengan Covid-19.

Di masa pandemi Covid-19, Asri dkk. (2021) melakukan kegiatan pengabdian kepada masyarakat dengan mengedukasi melalui penyuluhan melalui Posyandu pada masyarakat Dusun Keling Kalijaga Tengah di masa pandemi Covid-19. Penyuluhan tersebut terkait pola hidup sehat yang mencakup dua hal, yaitu: yang bersifat individual (meliputi pentingnya berolahraga dan asupan gizi untuk menjaga stamina tubuh, serta penerapan protokol kesehatan yang benar) dan yang bersifat umum yang terkait dengan lingkungan tempat tinggal (berupa pembersihan setiap gang RT/RW). Hasil penyuluhan ini menunjukkan terjadinya perubahan yang signifikan di masyarakat. Mereka memraktekkan protokol kesehatan

\footnotetext{
${ }^{4}$ Workout from home merupakan aktifitas fisik yang dilakukan di rumah dengan tujuan untuk menjaga kebugaran jasmani serta dapat meningkatkan imunitas
}

dengan benar, berolahraga, dan mengonsumsi makanan bergizi sebagai uipaya pencegahan Covid-19. Selain itu, lingkungan menjadi bersih karena masyarakat menyadari pentingnya membuang sampah pada tempatnya.

Studi Wahyuni (2020) tentang pola hidup sehat dalam kaitan dengan perawatan dan penyembuhan luka perinium pada ibu nifas menunjukkan bahwa prilaku hidup sehat sangat berpengaruh terhadap penyembuhan luka perinium ibu nifas. Prilaku hidup sehat tersebut berkaitan dengan pengetahuan, olah raga, gizi, dan personal hygiene ibu nifas. Artinya, prilaku hidup sehat sangat membantu dalam proses penyembuhan tersebut.

Ini berkelindan dengan temuan Riksandi dan Hidayat (2020) yang mengindikasikan signifikannya gerakan hidup sehat melalui media sosial Instagram di masa pandemi Covid-19. Dalam konteks ini, para milenial berperan dalam mengajak masyarakat untuk melakukan aktifitas workout from home ${ }^{4}$ melalui Instagram. Studi ini sangat berkaitan dengan salah satu aspek dalam pola hidup sehat, yaitu melakukan aktifitas fisik guna meningkatkan imunitas tubuh. Namun, penelitian ini tidak menyentuh aspek lain yang sangat berkaitan, yaitu pola makan yang sehat dan pola istirahat yang cukup. Artikel ini mengisi celah tersebut.

Pembahasan dalam artikel ini dibagi ke dalam tiga sessi. Sessi pertama mendiskusikan tentang GERMAS di Indonesia yang sangat erat kaitannya dengan proses pemutusan mata rantai penyebaran Covid-19. Sessi kedua mengeksplorasi persepsi mahasiswa tentang pola hidup sehat. Sessi ketiga mendemostrasikan penerapan pola hidup sehat mahasiswa di masa pandemi Covid-19.

tubuh yang tentunya sangat penting di masa pandemi seperti sekarang ini. 
Pola Hidup Sehat Mahasiswa di Masa Pandemi Covid-19...

\section{Metode Penelitian}

Penelitian ini dilakukan di kelurahan Tombolo, Kecamatan Somba Opu, Kabupaten Gowa. Pemilihan lokasi penelitian didasarkan pada pertimbangan bahwa di Kelurahan Tombolo yaitu jumlah kasus Covid-19 antara bulan Januari dan Desember 2020 sebanyak 101 orang dengan jumlah penduduk sekitar 18.000 orang. Ini jumlah yang relatif kecil dibandingkan dengan jumlah penduduknya. Namun, jumlahnya meningkat secara signifikan di tahun 2021, yakni 229 kasus untuk periode Januari hingga September 2021. Ini artinya ada pertambahan lebih dari dua kali lipat jika dibandingkan dengan tahun 2020. Penelitian ini mulai dilakukan antara bulan Oktober hingga Desember 2020, dan melakukan occasional visit dengan informan di tahun 2021.

Informan dalam penelitian ini berjumlah 10 orang yang terdiri atas lima orang laki-laki dan lima orang perempuan yang berstatus mahasiswa/i, alasan atas pemilihan informan tersebut dikarenakan informan tersebut berdomisili di kelurahan Tombolo dan berstatus mahasiswa. Mereka berusia antara 19 dan 23 tahun dan berdomisili di Kelurahan Tombolo, sebagaimana dijabarkan dalam Tabel 1 berikut ini.

\begin{tabular}{|c|c|c|c|c|}
\hline & \multicolumn{4}{|c|}{ Tabel 1. Informan Penelitian } \\
\hline No. & Nama & Usia (Tahun) & $\begin{array}{c}\text { Jenis } \\
\text { Kelamin }\end{array}$ & Status \\
\hline 1. & Rara & 20 & Perempuan & Mahasiswi \\
\hline 2. & Pude & 21 & Perempuan & Mahasiswi \\
\hline 3. & lis & 21 & Perempuan & Mahasiswi \\
\hline 4. & Nita & 22 & Perempuan & Mahasiswi \\
\hline 5. & Trisna & 22 & Perempuan & Mahasiswi \\
\hline 6. & Hadi & 23 & Laki laki & Mahasiswa \\
\hline 7. & Imam & 20 & Laki laki & Mahasiswa \\
\hline 8. & Riri & 22 & Laki laki & Mahasiswa \\
\hline 9. & Imamul & 22 & Laki-laki & Mahasiswa \\
\hline 10. & Nugrah & 19 & Laki-laki & Mahasiswa \\
\hline
\end{tabular}

Pengumpulan data dalam penelitian ini menggunakan metode wawancara mendalam. Dengan topik topik wawancara mencakup pandangan terkait pola hidup sehat yang dilakukan selama pandemi Covid-19, perubahan prilaku pola hidup sehat sebelum dan selama pandemi Covid-19.

Analisis data dalam penelitian ini dilakukan secara kualitatif deskriptif. Analisis deskriptif digunakan untuk mendapatkan gambaran secara rinci tentang objek penelitian melalui langkah-langkah sebagai berikut: menyeleksi data hasil wawancara, melakukan kategorisasi (persepsi, pola makan, pola kebersihan diri, pola tidur atau istirahat, aktifitas fisik atau olahraga), menafsirkan data, dan membuat kesimpulan.

Perizinan dilakukan secara lisan yang sifatnya informal dengan meminta izin terlebih dahulu kepada informan untuk melakukan wawancara dan perekaman selama wawancara berlangsugn. Waktu dan tempat wawancara 
disesuaikan dengan kesepakatan bersama mengingat informan juga memiliki aktifitas dan kesibukan yang berbeda beda. Semua nama informan adalah nama samaran.

\section{GERMAS di Indonesia}

GERMAS (Gerakan Masyarakat Hidup Sehat) adalah sebuah gerakan nasional yang dicanangkan oleh pemerintah RI diwakili Menteri Koordinator Bidang Pembangunan Manusia dan Kebudayaan RI, Puan Maharani, pada 15 November 2016 di Kabupaten Bantul, DI Yogyakarta, dan secara serentak dilakukan di sembilan lokasi lainnya, yaitu Kabupaten Bogor (Jawa Barat), Kabupaten Pandeglang (Banten), Kota Batam (Kepulauan Riau), Kota Jambi (Provinsi Jambi)Kota Surabaya (Jawa Timur), Kota Madiun (Jawa Timru), Kota Pare-Pare (Sulawesi Selatan), Kabupaten Pusbalingga (Jawa Tengah), dan Kabupaten Padang Pariaman (Sumatra Barat). Gerakan ini bertujuan untuk memasyarakatkan budaya hidup sehat serta meninggalkan kebiasaan dan perilaku masyarakat yang kurang sehat. Aksi GERMAS ini juga diikuti dengan memasyarakatkan perilaku hidup sehat dan dukungan untuk program infrastruktur berbasis masyarakat. Jika merujuk pada Inpres No. 1 Tahun 2017, kebijakan untuk mewujudkan GERMAS dilakukan melalui enam hal, yaitu: penignkatan aktivitas fisik, penignkatan perilaku hidup sehat, penyediaan pangan sehat dan percepatan perbaikan gizi, peningkatan pencegahan dan deteksi dini penyakit, penignkatan kualitas lingkungan, dan peningkatan edukasi hidup sehat. ${ }^{5}$

Program ini berfokus pada, misalnya, membangun akses untuk memenuhi kebutuhan air minum, instalasi kesehatan masyarakat, serta pembangunan pemukiman yang layak huni. Ketiganya merupakan infrastruktur dasar yang menjadi fondasi dari GERMAS. Namun ada tujuh bentuk kegiatan GERMAS, yaitu: (1) melakukan aktivitas fisik; (2) memakan buah dan sayur; (3) tidak merokok; tidak mengonsumsi minuman beralkohol; (4) melakukan cek kesehatan secara berkala [seperti cek kesahatan berat badan (BB) dan tinggi badan (TB) secara rutin; (5) cek lingkar perut dan bisa mengontrol lemak perut, cek tenkana darah, cek kadar gula darah berkala, cek fungsi mata telinga, cek kolesterol tetap (kolesterol buruk (LDL), kolesterol baik (HDL), dan Trigliserida, cek arus puncak ekspirasi, cek dan deteksi dini kanker leher Rahim, cek sadari periksa payudara sendiri]; (6) menjaga kebersihan lingkungan; (7) menggunakan jamban, sebagaimana dapat dilihat pada Gambar 1 berikut ini:

${ }^{5}$ https://www.germassejahtera.com/2020/02/bentukkegiatan.html, diakses tanggal 12 Agustus 2021. 


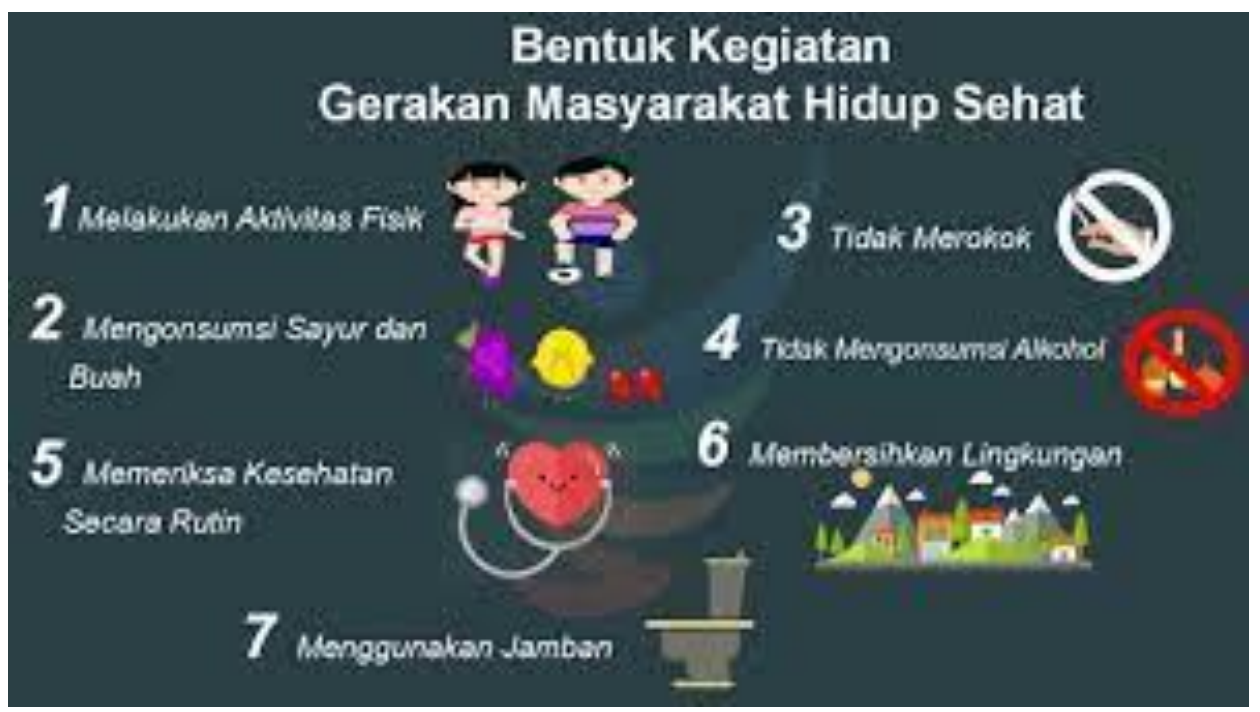

Gambar 1. Poster Bentuk Kegiatan GERMAS ${ }^{6}$

Di masa pandemi Covid-19, Menteri Kesehatan pada waktu itu, dr. Terawan Agus Putranto menghimbau kepada masyarakat Indonesia untuk menjaga kesehatan diri sendiri dan keluarga dengan berprilaku bersih dan sehat sebagai respon terhadap Covid-19 yang ketika itu awalnya terdeteksi di Cina. Ini karena menurut beliau hal yang paling baik dan murah dilakukan adalah pencegahan. Adapun langkah pencegahan dan menjaga diri dari Covid-19 adalah dengan menerapkan GERMAS yang meliputi: mencuci tangan pakai sabun, makan

\begin{abstract}
bergizi seimbang, berolahraga dan istirahat yang cukup, menjaga kebersihan lingkungan, tidak merokok, meminum air mineral delapan gelas/hari, makan makanan yang dimasak dengan sempurna dan jangan makan daging dari hewan yang berpotensi menularkan, bila demam dan sesak nafas segera ke fasilitas kesehatan, menggunakan masker bila batuk atau tutup mulut dengan lengan atas bagian dalam, dan berdoa (poster terkait dapat dilihat pada Gambar 2). ${ }^{7}$
\end{abstract}

\footnotetext{
${ }^{6}$ https://www.germassejahtera.com/2020/02/bentuk-kegiatan.html, diakses tanggal 12 Agustus 2021.

${ }^{7}$ https://promkes.kemkes.go.id/cegah-virus-corona-jaga-kesehatan-dengan-germas, diakses tanggal 12 Agustus 2021.
} 


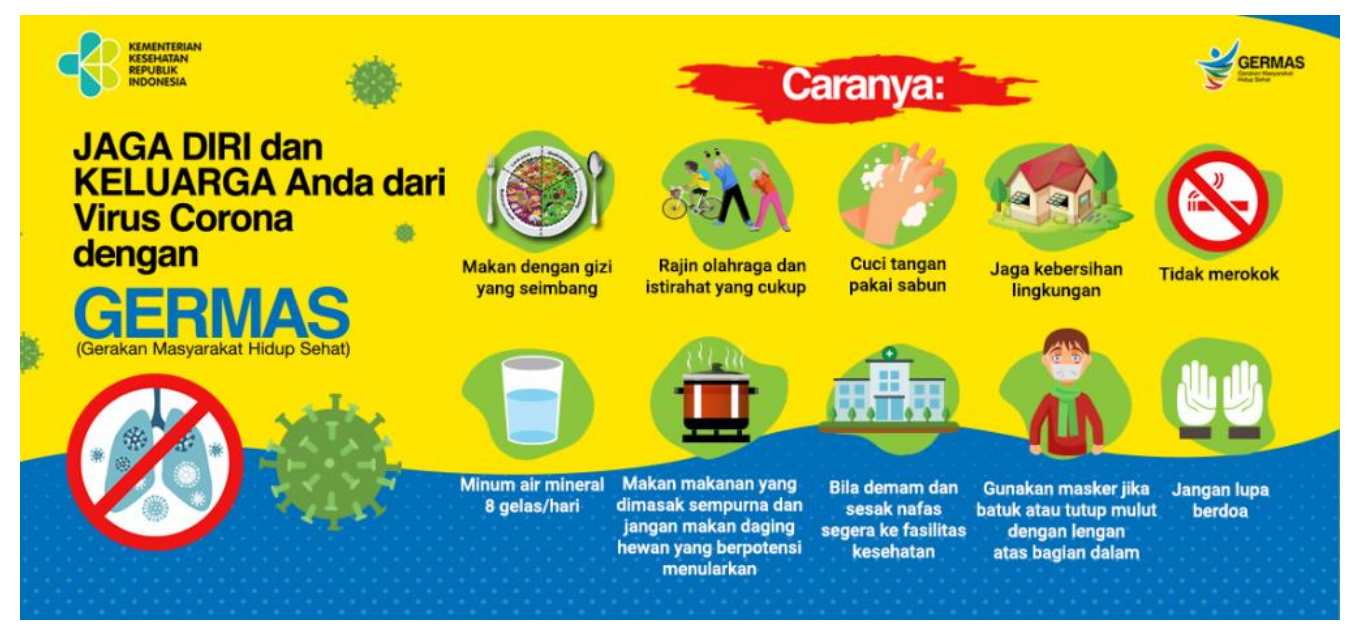

Gambar 2. Poster GERMAS di Masa Pandemi Covid-198

Ketujuh bentuk kegiatan tersebut sebenarnya bukan hal yang sulit dilakukan, namun seringkali terabaikan karena berbagai alasan, misalnya, kesibukan, ketidakpedulian, dan seringkali baru dilakukan jika ada sesuatu yang memaksa seseorang untuk melakukannya, seperti pandemi Covid-19. Di antara tujuh aspek GERMAS yang disebutkan di atas yang banyak dilakukan mahasiswa selama pandemi Covid-19 adalah gerakan fisik dan menjaga kebersihan lingkungan, terutama kebersihan diri sendiri. Ini menunjukkan bagaimana GERMAS berkelindan dengan upaya-upaya yang dilakukan untuk mencegah penularan Covid-19.

Di kelurahan Tombolo sendiri, pihak kelurahan menjelaskan bahwa, secara organisasi GERMAS belum ada, tetapi aktifitas terkait gerakan tersebut sudah seringkali diinisiasi oleh kelompok masyarakat, seperti PKK dan Posyandu. Pihak kelurahan juga menjelaskan bahwa pengaplikasian gerakan hidup sehat di Tombolo belum maksimal dikarenakan masih rendahnya kesadaran masyarakat terkait hal itu, termasuk pola hidup sehat. Pihak kelurahan sendiri masih berusaha untuk mengedukasi masyarakatnya terkait GERMAS dan pola hidup sehat.

Hal serupa juga menjadi jelas lantaran hanya beberapa informan yang mengetahui gerakan tersebut, selebihnya mereka menjelaskan bahwa gerakan yang pada dasarnya merupakan protokol kesehatan khususnya pada saat pandemi ini juga yang dilaksanakan di lingkungan mereka tidak maksimal. Rara (20 tahun), misalnya, menjelaskan bahwa gerakan gerakan tersebut kadang dilakukan sebagai tindakan kuratif (ketika sudah terjadi sesuatu atau orang mengalami penyakit), bukan sebagai tindakan preventif (untuk mencegah terjadinya suatu penyakit). Dalam kaitan dengan ini Hadi (23 tahun) menjelaskan bahwa penggunaan protokol kesehatan sendiri masih belum terlalu maksimal pengaplikasiannya.

\section{Mendefinisikan Pola Hidup Sehat}

Perilaku kesehatan, menurut Soekidjo (1993:59), pada dasarnya adalah "respon seseorang (organisme) terhadap stimulus yang berkaitan dengan sakit dan penyakit, sistem pelayanan kesehatan, makanan serta lingkungan". Di masa pandemi Covid-19, perilaku kesehatan

\footnotetext{
${ }^{8}$ https://perdhaki.org/category/germas/, diakses tanggal 12 Agustus 2021.
} 
Pola Hidup Sehat Mahasiswa di Masa Pandemi Covid-19...

mahasiswa lebih dikaitkan dengan bagaimana agar mereka tidak terinfeksi Covid-19, yakni dengan menerapkan pola hidup sehat. Bagaimana mahasiswa mendefinisikan pola hidup sehat?

Secara umum mereka memahami tentang pola hidup sehat itu sendiri, meskipun dalam prakteknya masyarakat tidak sepenuhnya menerapkan hal tersebut karena berbagai alasan kesibukan, adanya rasa malas, serta tidak memiliki kesempatan untuk memperhatikan prilaku pola hidup sehat itu sendiri, sebagaimana yang dituturkan beberapa informan berikut ini:

- Pola hidup sehat itu bagaimana manusia bisa menyayangi dirinya sendiri, dengan cara menjaga asupan makanan, serta melakukan aktifitas fisik, seperti berolahraga untuk menjaga tubuh agar tetap bugar dalam melakukan aktifitas apapun, karena dengan pola hidup sehat tubuh manusia juga akan lebih segar dan terhindar dari berbagai penyakit (Riri, 22 tahun).

- Pola hidup sehat itu mencakup tentang olahraga, mengonsumsi makanan dan minuman yang sehat, serta memilki mental yang sehat, untuk menciptakan kehidupan yang sehat, demi meningkatkan derajat kesehatan masyarakat, dan orang yang sehat adalah orang yang secara fisik maupun mentalnya juga sehat (Rara, 20 tahun).

- Pola hidup sehat itu segala kegiatan yang teratur menurut standar kesehatan seperti yang dilakukan mulai dari waktu tidur, waktu makan, dan kegiatan kegiatan yang baik dilakukan sesuai dengan standar kesehatan, serta mengkonsumsi makanan dan minuman yang sehat sesuai standar kesehatan (Hadi, 23 tahun).

- Pola hidup sehat yaitu rajin berolahraga, mengkonsumsi makanan bergizi, istirahat teratur. Yang paling penting menurut saya, yaitu istirahat dan makan karena kalau makan tidak teratur kan langsung drop (Imam, 20 tahun).

- Pola hidup sehat itu seperti berolahraga, makan yang teratur dan bergizi seperti makan 4 sehat 5 sempurna (Pude, 21 tahun).

- Pola hidup sehat itu menjaga kebersihan, rajin olahraga, makan teratur, tidak begadang (lis, 21 tahun).

- Pola hidup sehat itu hidup yang teratur, seperti olahraga, bangun dipagi hari, memakan makanan sehat, dan mental healing. Mental healing itu seperti tidak stress dan mencoba mencari kegiatan kegiatan yang positif (Imamul, 22 tahun).

- Pola hidup sehat itu seperti makan 4 sehat 5 sempurna, rajin meminum air putih, dan aktif bergerak (Nita, 22 tahun).

- Pola hidup sehat itu seperti waktu tidur yang 6 sampai 8 jam sehari, mengkonsumsi makanan sehat seperti sayuran dan buah buahan yang memiliki vitamin, protein yang seimbang, rutin berolahraga minimal 15 menit dalam seminggu (Trisna, 22 tahun).

- Pola hidup sehat itu rajin olahraga, menjaga pola makan, mengatur tidur atau istirahat, serta menjaga kebersihan (Nugrah, 19 tahun). 
Berbagai uraian di atas menunjukkan bahwa persepsi tentang pola hidup sehat pada intinya berkaitan dengan bagaimana seseorang memerhatikan makan/minum, kegiatan fisik (berolahraga), dan beristirahat sebagai upaya agar terhindar dari Covid-19.

\section{Penerapan Pola Hidup Sehat}

Menjaga pola hidup sehat dapat membuat seseorang terhindar dari segala macam penyakit dan virus, dan itu tidak terjadi begitu saja, harus ada upaya yang dilakukan untuk mewujudkan itu. Menurut Soenarjo (2002:17), untuk mewujudkan pola hidup sehat, maka ada sejumlah faktor yang memengaruhinya, yaitu yaitu: pola kebersihan diri, pola makanan dan minuman yang sehat, pola gerak badan atau olahraga, pola keseimbangan kegiatan, dan pola pencegahan dan kesehatan diri. ${ }^{9}$ Bagaimana mahasiswa menerapkan pola hidup sehat di masa pandemic Covid-19?

Dalam konteks penelitian ini, ditemukan tiga di antara cakupan yang dikemukakan oleh Soenarjo, yakni pola kebersihan diri, pola makan, dan pola gerak badan. Sementara, pola lainnya yang ditemukan adalah pola beristirahat dan ini diterapkan oleh mahasiswa untuk pencegahan penularan Covid-19, sebagaimana yang akan dibahas berikut ini.

\section{Pola Kebersihan Diri}

Kebersihan diri adalah hal yang sangat penting untuk diperhatikan karena akan menunjang kualitas kesehatan setiap manusia, terutama di masa pandemi seperti saat ini. Covid-19 merupakan virus yang menyebar melalui transmisi droplet (cairan yang keluar dari cipratan air liur melalui mulut, hidung pada saat batuk, bersin, maupun berbicara). Oleh karena

\footnotetext{
${ }^{9}$ https://www.duniamfb.my.id/2020/09/definisi-polahidup-sehat-menurut-para-ahli.htm, diakses tanggal 20 Juli 2021.
}

itu, menjaga kebersihan dan menjaga jarak menjadi sangat penting untuk diterapkan.

Sejak Covid-19 mewabah, pemerintah telah berupaya untuk melakukan berbagai cara untuk mencegah penularan Covid-19. Salah satu di antaranya adalah dengan gerakan 3M (menggunakan masker, menjaga jarak, dan mencuci tangan dengan sabun) dan $3 \mathrm{~T}$ (testing, tracing, dan treatment). Testing dan screening dilakukanterhadap orang yang terindikasi terpapar Covid-19; tracing dilakukan untuk melacak orang yang berinteraksi dengan seseorang yang sudah terpapar Covid-19; dan treatment dilakukan terhadap orang yang sudah terpapar Covid-19 dengan mengisolasikan diri dan tidak berinteraksi dengan orang lain. Gerakan yang dilakukan secara nasional di Indonesia menggunakan berbagai macam media platform, baik digital maupun konvensional. ${ }^{10} \quad$ Bagaimana mahasiswa menerapkan pola kebersihan diri mereka?

Imam (20 tahun), misalnya, menjelaskan bahwa perubahan pola kebersihan diri yang ia lakukan cukup dinamis tergantung situasi Covid19. Sebelum pandemi Covid-19, ia lebih sering mandi atau membersihkan badan sekali dalam sehari. Pada awal pandemi Covid-19, saat itu masih cukup ketat, ia menjadi lebih sering mandi apalagi jika baru pulang dari luar rumah. Pada saat sekarang, ketika situasi semakin longgar kebiasaan mandinya kembali seperti sebelum pandemi Covid-19. Hal serupa terjadi dalam kaitan dengan penerapan protokol kesehatan, terutama dalam hal memakai masker dan mencuci tangan, ia juga menjelaskan bahwa di awal pandemi cukup ketat dalam menjaga jarak, tapi untuk masa sekarang yang lumayan longgar sudah tidak terlalu, hanya saja masih

\footnotetext{
${ }^{10} \mathrm{https}: / /$ prodi.vokasi.uns.ac.id/komunikasi/2021/06/0 9/upaya-pencegahan-covid-19-dengan-3m-dan-3t/, diakses tanggal 27 Agustus 2021.
} 
Pola Hidup Sehat Mahasiswa di Masa Pandemi Covid-19...

menggunakan masker ketika berintraksi secara dekat dengan orang lain.

Ini berbeda dari Rara (20 tahun) yang menurutnya selama pandemi ia lebih sering mencuci tangan dan menggunakan handsanitizer dibandingkan sebelum pandemi. Jika ia keluar rumah ia lebih sering langsung mandi dan mengganti pakaiannya. Perubahan serupa namun lebih ekstrim dilakukan oleh Riri (22 tahun) sebelum pandemi ia cukup sering mencuci tangan karena memang dia cukup higienis dalam beraktifitas dan menggunakan masker saat mengendarai motor. la juga mandi dua kali sehari dan pakaian kotornya ditumpuk dulu menunggu cucian lainnya hingga beberapa hari sebelum dicuci. Sejak pandemi Covid-19, saat dirinya lebih banyak menghabiskan waktu di rumah, jadwal mandinya justru berubah dari dua kali menjadi satu kali dalam sehari. Namun, jika ia beraktifitas di luar rumah, ia langsung mandi dan langsung mencuci pakaiannya. la lebih sering mencuci tangan dan menggunakan handsanitizer, serta selalu memakai masker dalam beraktifitas di luar rumah.

Pude (21 tahun) menyadari bahwa ada perbedaan yang signifikan yang terjadi pada dirinya sebelum dan selama pandemi Covid-19. Sebelum pandemi Covid-19, ia jarang mencuci tangan, tidak memakai masker sama sekali, dan mandi paling banyak dua kali sehari. Selama pandemi Covid-19, ia menjadi sering mecuci tangan dan menggunakan handsanitizer dan masker, mandi apalagi setelah keluar rumah, ia bisa mandi sampai tiga kali sehari. Untuk menjaga jarak sendiri pada saat pandemi ia hanya menyesuaikan dengan aturan di ruang publik dan juga tetap menjaga jarak meski tidak terlalu ketat.

Contoh lainnya adalah Hadi (23 tahun) yang selama pandemi apalagi saat pembatasan sosial berskala besar (PSBB) ia lebih sering mencuci tangan, menggunakan handsanitizer, serta memakai masker, tetapi saat PSBB berakhir, ia tidak sesering lagi melakukan semua itu. Kalau untuk persoalan jaga jarak ia hanya menyesuaikan dengan aturan di tempat publik dimana ia berada, ketika tempat publik itu menerapkan protokol kesehatan dengan ketat hingga harus menjaga jarak maka ia akan menjaga jarak, sedangkan ketika aturannya tidak terlalu ketat ia hanya akan biasa saja dalam beinteraksi. Hal serupa juga terjadi pada Imamul (22 tahun), bahwa ketika sebelum pandemi ia lebih sering mandi bisa 3 sampai 4 kali dalam sehari, seperti pada saat pergi dan pulang dari kampus dan juga ketika pulang dari mengajar serta jika ia merasa gerah di malam hari. Selama pandemi Covid-19, jadwal mandinya justru berkurang karena ia jarang keluar. la juga sangat konsisten dengan pemakaian masker. Sementara untuk menjaga jarak, ia hanya menyesuaikan dengan kondisi setempat, tergantung keketatan aturan atau kelonggaran jaga di ruang-ruang publik dimana ia berada.

Hal berbeda terjadi pada Trisna (22 tahun), bahwa sebelum pandemi ia mandi lebih sedikit dibanding pada saat pandemi karena ketika pandemi aktifitasnya berkurang, banyak menghabiskan waktu di rumah, dan justru membuatnya lebih sering mandi. Penyebab lainnya adalah karena ia memiliki alergi makanan, seperti telur, ayam, udang dan makanan seafood lainnya, sehingga ia lebih menjaga kebersihan tubuhnya. Meskipun sebelum pandemi ia lebih jarang mandi, ia tetap rajin untuk mencuci tangan. Di masa pandemi Covid-19, kebiasaan itu berlanjut, namun disertai dengan penggunaan handsanitizer dan masker, serta menjaga jarak ketika sedang berinteraksi dengan orang lain.

Jika merujuk pada kutipan-kutipan di atas, ini mengindikasikan bahwa ada perubahan yang terjadi dari kebiasaan-kebiasaan sebelum dan selama pandemi dalam kaitan dengan 
kebersihan diri mereka. Di antara 3M yang dianjurkan pemerintah, mencuci tangan/membersihkan tangan handsanitizer dan mandi adalah dua hal yang paling common dilakukan oleh mahasiswa, untuk menjaga jarak sendiri terkadang mahasiswa hanya menyesuaikan dengan kondisi ruang publik dimana mereka berada. Jika aturan protokol kesehatannya cukup ketat, maka mereka lebih waspada dalam menjaga jarak.

\section{Pola Makan}

Pola makan merupakan salah satu aspek yang penting dalam pola hidup sehat karena dengan mengonsumsi makanan dan minuman yang sehat serta jadwal makan yang teratur akan membuat seseorang daya tahan untuk beraktifitas sehari-hari. Menurut Sumintarsih, (2008:14) pola makanan yang sehat adalah pola makan yang seimbang antara karbohidrat, protein, lemak, vitamin, mineral, air, dan serat makanan. Kriteria makanan yang sehat adalah 4 sehat 5 sempurna. Namun, pola ini tidak cukup jika tidak dilengkapi dengan kriteria makanan sehat berimbang yang mencakup kuantitas, proporsional, berkualitas, sehat, segar alami, ber-nabati, dengan cara memasak yang benar, dengan penyajian yang teratur, dan dengan meminum air delapan gelas sehari. Bagaimana pola makan mahasiswa selama masa pandemi Covid-19?

Sebelum pandemi Covid-19, Imam (20 tahun) lebih sering menghabiskan waktunya di kampus karena jadwal kuliahnya yang padat dan meskipun ia selalu sarapan di rumah, ia lebih banyak makan siang di luar. Ini berubah sejak Covid-19 mewabah, ia lebih banyak menghabiskan waktunya di rumah karena kuliah dilakukan secara daring dan dengan demikian ia juga lebih banyak makan di rumah. la biasanya makan tiga kali sehari dengan menu yang berbeda, namun selalu harus dengan nasi karena ia merasa lemas jika tidak mengonsumsi nasi, termasuk di pagi hari. Namun selama pandemi Covid-19, ia banyak mengonsumsi sayuran dan buah-buahan, terutama yang mengandung vitamin $C$, serta lebih banyak minum air putih untuk menjaga kesehatan dan daya tahan tubuhnya.

Ini sedikit berbeda dengan Hadi (23 tahun) yang sebelum pandemi Covid-19, ia sarapan lebih pagi di rumah karena harus pergi ke kampus untuk kuliah, selanjutnya makan siang di kampus dengan menu yang bervariasi karena kantin banyak tersedia di kampus. Selama pandemi Covid-19, jadwal sarapannya justru sering terlambat atau tidak sama sekali karena ia sering bangun terlambat. la dan anggota keluarganya yang lain lebih banyak makan di rumah, tidak saja karena mereka lebih banyak menghabiskan waktu di rumah, tapi juga karena mereka takut mengorder makanan dari luar, terutama di masa PSBB.

Menurut Riri (22 tahun), sebelum pandemi Covid-19, ia makan tiga kali sehari (sarapan, makan siang, dan makan malam. Bedanya, di masa pandemi Covid-19, ia lebih sering makan makanan rumahan karena merasa lebih sehat dan juga lebih terjamin mutu dan higienitasnya. Sebelum pandemi Covid-19, ia lebih sering mengonsumsi makanan di luar karena lebih sering berada di luar rumah, terutama untuk kuliah. Namun di masa pandemi Covid-19, ia lebih sering mengonsumsi buah buahan yang disediakan oleh orang tuanya di rumah, dan lebih banyak mengonsumsi air putih untuk menjaga daya tahan tubuhnya.

Contoh kasus lainnya adalah Pude (21 tahun). la menjelaskan bahwa jadwal makannya sebelum pandemi hanya dua kali dalam sehari karena ia jarang sarapan. Tapi jadwal makan siangnya lebih awal, yakni antara jam 11.00 dan 12.00 dan lebih sering makan di luar atau di sekitar kampus karena ia memang lebih banyak 
menghabiskan waktunya di kampus. Ini berubah secara signifikan selama pandemi Covid-19 karena ia lebih banyak di rumah, sehingga ia lebih sering menkonsumsi makanan rumahan atau yang dimasak oleh ibunya. Dengan makan di rumah, jadwal makannya berubah menjadi tiga kali sehari (pagi, siang, dan malam) dan lebih teratur. la juga banyak mengonsumsi sayuran yang disediakan ibunya dibandingkan sebelum pandemi.

Makan dua kali sehari adalah kebiasaan Rara (20 tahun), baik sebelum maupun selama pandemi Covid-19. Jika di pagi hari ia sarapan dengan roti, maka di siang hari ia makan makanan berat (nasi). la jarang makan malam dengan makanan berat, tapi ia selalu ngemil (makan snack dan semacamnya). Pada saat sebelum pandemi ia lebih sering mengonsumsi makanan cepat saji karena sering berada di luar rumah. Selama pandemi Covid-19, kebiasaan buruk ini berubah secara drastis, ia tidak lagi mengonsumsi makanan cepat saji karena sudah jarang berada di luar rumah, dan menurutnya itu memang tidak sehat.

Nugrah (19 tahun) menjelaskan bahwa sebelum pandemi ia bisa makan sampai empat kali dalam sehari dan cukup banyak memakan makanan yang berlemak dan malas untuk mengonsumsi buah dan sayuran. Selama pandemi ia merubah pola makannya tidak saja dengan membiasakan diri memakan sayur dan buah serta mengurangi karbohidrat, tapi juga berolah raga untuk menurunkan berat badan dan menjaga imunnya.

Perubahan lainnya terjadi pada Nita (22 tahun), bahwa selama pandemi Covid-19, ia lebih banyak menghabiskan waktu di rumah, sehingga jadwal makannya lebih teratur dan terkontrol dan juga makanan yang dikonsumsi adalah makanan yang disediakan dirumah, sebagai salah satu upaya untuk menghindari interaksi dengan orang luar. Ini berkelindan dengan apa yang diungkapkan oleh Riri (23 tahun) bahwa selama pandemi Covid-19 ia lebih sering makan di rumah agar lebih sehat dan makanan yang dikonsumsi juga lebih terjamin kebersihannya.

Kutipan-kutipan di atas menunjukkan bahwa perubahan yang paling nampak dalam kaitan dengan pola makan adalah: pertama, makanan yang dikonsumsi, yakni dari makanan luar ke makanan rumah; kedua, jenis makanan yang dikonsumsi (makanan sehat) dan ketiga, jadwal makan (bertambah, lebih teratur). Perubahan ini terjadi karena mereka lebih banyak menghabiskan waktu di rumah ketimbang di luar rumah, tapi juga karena mereka berupaya untuk meminimalkan sesuatu yang berasal dari luar untuk menghindari transmisi virus.

\section{Pola Gerak Badan}

Salah satu aspek yang dapat menunjang peningkatan imunitas tubuh adalah dengan melakukan aktifitas fisik/olahraga karena dengan melakukan olahraga ini akan meningkatkan metabolisme tubuh dan membuat tubuh menjadi lebih kuat dan segar. Di masa pandemi Covid-19, salah satu yang banyak dilakukan orang untuk menjaga imunitas tubuh adalah dengan berolah raga. Bagaimana olah raga mahasiswa di masa pandemi Covid-19?

Sebelum pandemi Covid-19, jadwal olah raga Hadi (23 tahun) tiga sampai empat kali dalam seminggu. la tidak saja ber-jogging atau renang sekali dalam seminggu, tapi juga terkadang melakukan olahraga di rumah seperti push up atau berolah raga dengan mengikuti tutorial secara online jika sedang good mood. Selama pandemi Covid-19, terutama di masa PSBB, ia justru jarang sekali berolahraga karena ia merasa malas, padahal ia banyak memiliki waktu di rumah. Namun, selepas PSBB ia mulai kembali berolahraga secara rutin dengan jenis olah raga yang lebih bervariasi, seperti renang, 
bulutangkis, jogging, push up, sit up, dll. karena pemerintah sudah sedikit melonggarkan masyarakat untuk keluar rumah dengan tetap mematuhi protokol kesehatan.

Hampir sama dengan Hadi, Imam (20 tahun) yang menjelaskan bahwa sebelum pandemi Covid-19 ia lebih sering berolahraga seperti bermain futsal yang jadwalnya lebih fleksibel dan biasanya ia lakukan dua kali dalam seminggu. la juga terkadang melakukan jogging dan bersepeda. Pada saat pandemi ia merasa lebih jarang berolahraga karena ia menjadi malas beraktifitas di rumah. Setelah PSBB berakhir, la kembali berolahraga dengan jenis olah raga yang tren di masa pandemi Covid-19, yaitu bersepeda. Namun itupun hanya pada hari Minggu karena aktivitas perkuliahan kembali padat meskipun itu dilakukan secara daring.

Sementara Riri (22 tahun) juga menjelaskan sebelum pandemi lebih sering olahraga bahkan hampir setiap hari tapi intensitas waktunya yang singkat menyesuaikan waktu luang dan gerakannya juga tidak terlalu banyak hanya seperti push up atau skipping dan juga kalau malam sebelum tidur melakukan perenggangan. Selama pandemi waktu olahraga tidak sesering sebelum pandemi (hanya tiga sampai empat kali dalam seminggu) karena terlalu banyak waktu di rumah tanpa kegiatan, sehingga ia menjadi malas untuk bergerak atau berolahraga. Gerakan olahraganya juga lebih bervariasi dibandingkan sebelum pandemi seperti gerakan menggunakan beban atau barbel serta menggunakan treadmill, atau skipping dan juga melakukan gerakan jumping jack.

Ini berbeda dengan apa yang dilakukan oleh lis (21 tahun) yang lebih sering berolahraga basket di kampus, khususnya di Unit Kegiatan Mahasiswa (UKM) Olahraga kampus. Sebelum pandemi Covid-19, jadwal olahraganya lebih sering (tiga kali seminggu) mengikuti jadwal latihan di UKM. Selama pandemi kegiatan olah raganya menjadi berkurang (paling banyak dua kali seminggu). Namun, jadwal ini semakin berkurang pada saat PSBB karena kampus dan UKM ditutup.

Rara (20 tahun) mengungkapkan bahwa ada sedikit perubahan yang terjadi dalam kaitan dengan kegiatan berolah-raga-nya. la berolahraga di rumah dengan bantuan tutorial gerakan secara online karena terinspirasi oleh selebgram (selebriti Instagram) untuk mengisi kekosongan di rumah selama pandemi. la lebih suka berolah raga di rumah ketimbang di luar rumah, bukan saja karena ia malas, tapi juga karena selama pandemi Covid-19, ia lebih suka beraktivitas di rumah daripada di luar rumah untuk menghindari interaksi dengan orang lain., menghindari penularan Covid-19. Serupa dengan Rara, Trisna (22 tahun) menjelaskan bahwa baik sebelum dan selama pandemi ia sangat malas untuk berolahraga karena ia malas mempersiapkan perlengkapan untuk berolahraga, sehingga ia sangat jarang berolahraga. Hal berbeda diungkapkan oleh Nugrah (19 tahun) bahwa sebelum pandemi ia tidak pernah berolahraga, tetapi selama pandemi ia sangat aktif dalam berolahraga setiap hari, salah satu alasannya karena ingin menurunkan berat badan dan menjaga imun. Adapun jenis olahraga yang rutin ia lakukan, yaitu fitness, jogging, futsal, dan bulu tangkis.

Berdasarkan kutipan-kutipan di atas, olah raga menjadi kegiatan yang dilakukan karena dipercaya dapat menjaga kondisi tubuh agar tetap fit, meskipun ada beberapa informan yang juga menyatakan bahwa sangat jarang untuk berolahraga baik sebelum maupun selama pandemi karena memang malas untuk melakukannya. Perubahan yang terjadi tidak saja dalam kaitan dengan intensitas berolah raga, tapi juga dengan jenis olah raga.

\section{Pola Beristirahat}


Beristirahat merupakan salah satu kunci untuk menjaga kesehatan serta daya tahan tubuh dikarenakan pada saat istirahat tubuh akan memulihkan kembali selsel yang rusak dan energi yang terpakai pada saat melakukan aktifitas fisik atau berolahraga. Selain itu, proses metabolisme (proses tubuh dalam mencerna, menyerap, dan mengasimilasi makanan diubah menjadi energi) pada saat tubuh dalam kondisi tertidur. Tapi tidak semua orang memerhatikan waktu beristirahat mereka. Bagaimana dengan pola beristirahat mahasiswa?

Menurut Imam (20 tahun) sewaktu sebelum pandemi sering kurang tidur dan begadang, sedangkan pada saat pandemi tidurnya menjadi lebih banyak (lebih dari 8 jam sehari) yang lebih banyak, meskipun juga masih begadang, dan dengan karena waktu luang jadwal tidur yang lebih tidak teratur. Sebelum pandemi jadwal tidur yang paling sering itu jam dua pagi karena banyak tugas kampus dan organisasi. Pada waktu weekend (akhir minggu), ia tidur lebih cepat. Sebelum pandemi jadwal tidur paling cepat pada pukul 10 malam, dan jadwal bangunnya kadang pukul lima atau jam enam pagi untuk shalat subuh. la kemudian kembali tidur hingga jam tujuh atau delapan pagi. Sedangkan pada saat pandemi jadwal tidurnya paling sering itu jam 12 malam dan bangun jam lima kemudian kembali tidur. Dia juga menjelaskan bahwa sebelum pandemi kadang ia tidur pada siang hari dan menyesuaikan dengan jadwal kegiatannya jika tidak padat, dengan durasi antara 30 menit sampai satu jam. Selama pandemic Covid-19 jadwal tidurnya justru menjadi tidak teratur kadang ia tidur siang, tapi tidak tidur malam, atau sebaliknya.

Menurut Hadi (23 tahun), sebelum masa pandemi Covid-19, ia paling cepat tidur jam sebelas malam dan paling lambat jam satu pagi. Meskipun tidurnya telat, ia tetap menunaikan sholat Subuh, kemudian ia melanjutkan tidurnya dan bangun antara jam sembilan dan sebelas pagi, itupun bila ia tidak memiliki jadwal kuliah pagi. Tidur telat di malam hari seringkali disebabkan oleh kebiasaannya tidur sore (antara jam tiga dan jam enam) dan menonton film hingga larut malam. Selama pandemi Covid-19, jadwal tidurnya semakin telat, yakni antara jam 12.00 dan jam tiga pagi. la bahkan terkadang tidak tidur hingga pagi jika ia keasyikan mengerjakan tugas atau bermain game. Hal serupa terjadi pada Rara (20 tahun), yang sebelum pandemi Covid-19, jadwal tidurnya antara jam sepuluh dan jam sebelas malam. Namun selama pandemi, ia semakin sering begadang hingga jam satu pagi. Ini karena ia tidak memiliki banyak aktivititas di siang hari yang dapat membuatnya cepat mengantuk pada malam hari. Ini membuatnya sering terlambat bangun pagi karena meskipun ia bangun sholat Subuh, ia melanjutkan tidur setelahnya.

Hal ini berbeda dari pola beristirahat dari Riri (22 tahun) yang sebelum pandemi sering begadang karena ia seringkali keluar untuk nongkrong, sehingga terkadang lupa waktu. Jika ia tidak begadang, maka ia paling cepat tidur setelah sholat Isya, bangun saat sholat Subuh, dan tidak tidur kembali. Tapi ia lebih sering tidur telat, yakni antara jam 12.00 dan jam satu pagi, dan bangun paling lambat antara jam enam dan tujuh pagi. Jikapun ia tidur siang, waktunya hanya sekitar 15 menit. Selama pandemi Covid19 , jadwal tidurnya lebih tidak teratur dan waktu begadangnya jadi lebih lama, yakni hingga jam tiga pagi. Ini berkelindan dengan jadwal bangunnya, yakni antara jam sepuluh dan jam sebelas pagi. Namun selama pandemi Covid-19, ia jarang sekali memiliki waktu untuk tidur siang karena ini berkaitan dengan kegiatan kuliah daring. Oleh karena ia lebih banyak menghabiskan waktu di rumah, ini seringkali membuatnya merasa bosan. Salah satu aktifitas 
untuk menghilangkan kebosanan itu adalah dengan menonton film atau mendengarkan musik dan ini berkontribusi terhadap terganggunya jadwal tidur malamnya.

Berbeda halnya yang dialami oleh Pude (21 tahun) dia menjelaskan bahwa sebelum pandemi Covid-19 ia paling cepat tidur jam sebelas malam. Kalaupun ia begadang, maka itu paling lama hingga jam tiga atau jam empat pagi, itupun jika ia harus mengerjakan tugas kuliah. Selama pandemi ia seringkali tidur di sing hari (antara jam dua dan jam tiga) karena ia lebih banyak menghabiskan waktunya di rumah. Ini yang menyebabkan ia begadang di malam.

lis (21 tahun) juga menjelaskan bahwa pada saat sebelum pandemi Covid-19, ia paling sering begadang hingga pada jam 12 . Selama awal pandemi Covid-19 ia juga jarang begadang, Tapi, seterlambat apapun tidur malamnya, ia tidak pernah meninggalkan shalat Subuh-nya. Sedangkan selama pandemi kadang tidur malamnya pada jam sepuluh malam dan bangun pada jam lima pagi, dan tidak tidur lagi. Pada saat PSBB, ia jauh lebih cepat tidur, dan pada saat pemerintah mulai merenggangkan kepada masyarakat untuk berinteraksi secara terbatas, namun justru membuatnya jadi lebih sering begadang.

Nita (22 tahun) menyatakan bahwa selama pandemi ia biasanya tidur jam 10 malam dibandingkan pada saat sebelum pandemi Covid19. Sedangkan pada saat pandemi ia tidur sejam lebih cepat dari sebelumnya karena kurangnya aktifitas atau kegiatan di malam hari. Hal serupa diungkapkan oleh Trisna (22 tahun) bahwa sebelum pandemi ia mulai tidur itu jam sepuluh dan bangun antara jam lima dan jam tujuh pagi. Sedangkan selama pandemi Covid-19, ia tidur lebih cepat yaitu antara jam delapan dan jam sembilan malam jika tidak ada aktifitas yang dilakukan.
Jika merujuk pada kutipan-kutipan di atas, maka ada perubahan yang signifikan pada pola istirahat mahasiswa adalah jadwal tidur yang terkadang berubah menjadi lebih cepat untuk tidur di malam hari di masa pandemi Covid-19 karena kurangnya aktifitas. Namun, ada juga yang justru menjadi lebih lama untuk tidur atau beristirahat karena mengalihkan kekosongan aktifitas dengan kegiatan lain, seperti bermain game dan menonton film sehingga jadwal tidur malam menjadi terganggu.

\section{Kesimpulan}

Cara manusia hidup akan menentukan bagaimana kualitas hidupnya, ketika manusia menjaga kualitas hidupnya agar tetap positif dan produktif, maka hal itupun juga akan membawa pengaruh yang baik terhadap kondisi fisik dan psikis mahasiswa. Secara teoritis ini memperpanjang usia harapan hidup dan membuat hidup lebih bahagia. Adapun salah satu cara untuk mendapatkan kualitas hidup yang lebih baik dan positif adalah dengan tetap menjaga pola hidup sehat, terutama di masa pandemi Covid-19.

GERMAS yang telah dicanangkan pemerintah sejak tahun 2016, yang pada dasarnya merupakan gerakan untuk membudayakan hidup sehat beririsan dengan gerakan-gerakan yang juga dilakukan selama pandemi Covid-19 untuk memutus mata rantai penyebaran virus Covid-19. Di Kelurahan Tombolo sendiri, gerakan ini masih belum terlaksana secara maksimal, dikarenakan masih kurangnya kesadaran masyarakat umum terkait hal tersebut. Pihak kelurahan sendiri masih berusaha untuk mengedukasi masyarakatnya. Bentuk penerapan protokol kesehatan di lingkungan tempat tinggal juga masih kurang maksimal karena masih banyak orang yang memandang sebelah mata tentang protokol kesehatan, bahkan melanggar protokol tersebut. 
Namun, meskipun tidak sepenuhnya sempurna, mahasiswa lebih peka terhadap pola hidup sehat Covid-19, sehingga protokol kesehatan turut menjadi perhatian mereka.

Pola hidup bagi mahasiswa mencakup pola kebersihan diri, pola makan, pola berolah raga, dan pola beristirahat. Dalam penerapannya, pola hidup sehat mahasiswa di masa sebelum dan selama pandemi Covid-19 cukup bervariasi dan dinamis, baik dalam bentuk pola kebersihan diri, pola makan, pola berolah raga, maupun pola beristirahat.

Di masa pandemi Covid-19, pola kebersihan diri yang paling signifikan perubahannya, tidak saja karena anjuran pemerintah untuk mematuhi protokol kesehatan (mencuci tangan, menjaga jarak, dan memakai masker), tapi ini juga menjadi kebiasaan baru untuk pencegahan penularan Covid-19. Pola makan mahasiswa juga menunjukkan perubahan yang signifikan, mulai dari jenis makanan dan minuman dikonsumsi (lebih sehat dan makanan rumahan), jadwal makan (lebih teratur).

Berolahraga menjadi salah satu kegiatan yang cukup mendapatkan perhatian di masa pandemi Covid-19. Yang tidak pernah berolah raga menjadikan olah raga sebagai salah satu kegiatan rutin, sementara yang berolah raga sejak sebelum pandemi Covid-19 semakin rutin melakukan kegiatan tersebut. Ini karena mereka percaya bahwa dalam tubuh yang sehat, ada virus yang takut, tetapi meskipun demikian tetap ada saja beberapa mahasiswa yang sebelum maupun selama pandemi masih merasa malas untuk berolahraga.

Pola beristirahat juga cukup terdampak dengan adanya pandemi Covid-19 dimana perubahan prilaku atau kebiasaan jadwal beristirahat juga dialami oleh mahasiswa. Dengan banyak waktu yang dihabiskan di rumah, waktu beristirahat menjadi beragam: ada yang lebih banyak tidur, ada yang kurang tidur di malam hari, tapi ada juga yang justru jadwal tidurnya menjadi terganggu karena waktu tidur digunakan untuk menonton film, bermain game atau mengerjakan tugas kuliah yang banyak diberikan oleh dosen.

GERMAS masih perlu digalakkan agar membudayakan pola hidup sehat sebagai bagian dari rutinitas, terlepas adanya pandemi atau tidak. Penelitian ini memiliki banyak keterbatasan, terutama terkait dengan keberagaman mahasiswa (eksak, non-eksak), status sosial (kaya-miskin), latar belakang budaya, sehingga penelitian lanjutan dan mempertimbangkan aspek-aspek tersebut untuk dicakupkan agar dapat memahami pola hidup sehat masyarakat secara lebih kompleks.

\section{Daftar pustaka}

Ardiyanto, A.; Purnamasari, V.; Sukamto; dan S, Sari, E. 2020. "Analisis Perilaku Hidup, Bersih dan Sehat di Era Pandemi Covid19 Dosen PGSD", Jendela Olahraga, Juli, 5(2):131-140,

http://journal.upgris.ac.id/index.php/je ndelaolahraga/article/view/6216, diakses tanggal 17 September 2020.

Asri, I. H.; Lestarini, Y.; Husni, M.; Muspita, Z.; Hadi; dan Y.A. 2021. "Edukasi Pola Hidup Sehat Di Masa Covid-19", Jurnal Abdi Populika, Januari, 2(1):56-63, https://ejournal.hamzanwadi.ac.id/index.php/ abdipopulika/article/view/3105/pdf 17, diakses tanggal 10 Agustus 2021.

Susanti, E. dan Nur Kholisoh. 2018. “Konstruksi Makna Kualitas Hidup Sehat: Studi Fenomenologi Pada Anggota Komunitas Herbalife Klub Sehat Ersanddi Jakarta", Jurnal Lugas, 2(1):1-12, https://ojs.stiami.ac.id/index.php/lugas Larticle/view/117, diakses tanggal 21 
September 2020.

Riksandi, D. dan Hidayat, D. 2020. "Gerakan Hidup Sehat Melalui Workout from Home di Instagram Pada Masa Pandemi Covid-19", Universitas Adhirajasa Reswara Sanjaya http://sinta.ristekbrin.go.id/covid/penel itian/detail/526, diakses tanggal 21 September 2020.

Rosidin, J. A. 2012. Pola Hidup Sehat Siswa Kelas $\checkmark$ sd Negeri 1 Karangcegak Kutasaripurbalingga. Skripsi, Fakultas Ilmu Keolahragaan, Universitas Negeri Yogyakarta, Yogyakarta.

Sani, F. N. 2009. Hubungan Tingkat Pengetahuan Sehat - Sakit Dengan Sikap Mahasiswa Universitas Muhammadiyah Surakarta Tentang Perilaku Hidup Bersih dan Sehat. Skripsi, Fakultas Ilmu Kesehatan, Universitas Muhammadiyah Surakarta, Surakarta.

Sumintarsih. 2008. Menjaga Berat Badan Ideal Dengan Pola Hidup Sehat. Yogyakarta: FIK UNY.

Susanti, E. dan Nur Kholisoh. 2018. "Konstruksi Makna Kualitas Hidup Sehat: Studi Fenomenologi Pada Anggota Komunitas Herbalife Klub Sehat Ersanddi Jakarta", Lugas Jurnal Komunikasi, Juni 2018, 2(1): 1-12, https://ojs.stiami.ac.id/index.php/lugas Larticle/view/117, diakses tanggal 21 September 2020.

Utama, L. J. 2020. “Gaya Hidup Mayarakat Nusa Tenggara Timur Dalam Menghadapi Pandemi Corona Virus Disease 19", AnNadaa: Jurnal Kesehatan Masyarakat, Juni 2020, 7(1):34-40, https://ojs.uniskabjm.ac.id/index.php/ANN/article/view/
2994, diakses tanggal 21 September 2020.

Wahyuni, I. 2020. "Perilaku Perawatan Luka Perinium, Pola Hidup Sehat dan Kondisi Kesehatan Ibu Post Partum Masa Pandemi Covid-19", Jurnal Kebidanan Harapan Ibu Pekalongan, Agustus 2020, 7(2):64-77, https://doi.org/10.37402/jurbidhip.vol7 .iss2.92, diakses tanggal 21 September 2020. 